\title{
7 To End the Yoke of Marriage: Mary Hunter Austin and the Struggle Against Patriarchal Norms
}

\section{Introduction}

For the author Mary Hunter Austin (1868-1934), the most important thing that a woman should achieve was being able to take care of herself by her own labor. Austin considered this claim not to be a recommendation but an encouragement for women. She herself was a strong advocate for every woman being able to take care of themselves and of their economic independence, no matter if a woman was working for her husband in the house or for someone else in the factory or office. This independence was important and should be achieved by "the married women just as much as [by] the unmarried ones." 1 The home was not a place to be on display like an ornament for women, Austin believed, but a place to gather oneself to excel in the outside world, and the way to such an achievement was based on the trinity of equal marriage, labor, and the ownership of one's own citizenship. The road to this idea's fulfillment was a long one, impacted by one's family, social norms like marriage or divorce, and a life led according to eclecticism and a hunger for change. The many ways Austin contributed to the female struggles in relation to gender norms, sexuality, marital issues, and other social problems were notable both in her own time as well as today. The politically left author was in general a strong advocate for love and kinship, but she also pointed to ways these things could be improved.

Mary Hunter Austin was born 9 September 1868 in Carlinville, Illinois as the fourth of six children of George Hunter (1830 - 1878) and Susanna Graham Hunter (1842-1896). Although especially her mother was everything but encouraging with regard to Austin's education, she graduated from college with a teaching degree, and she further evolved while lecturing and writing in the years to come. Austin was first and foremost a landscape writer who advocated for Native American rights, and she was later deemed proto-feminist in New York City and rediscovered by modern scholars. ${ }^{2}$

1 “Mrs. Well Known Says," The Hattiesburg News, January 18, 1911: 5.

2 For further reading, see Jowan A. Mohammed, "Mary Hunter Austin und die Forderungen nach einer Veränderung der Geschlechterrollen in den USA, 1914-1918," in Geschlecht und Klas-

Ә OpenAccess. () 2021 Jowan A. Mohammed, published by De Gruyter. (cc) BY-NC-ND This work is licensed under the Creative Commons Attribution-NonCommercial-NoDerivatives 4.0 International License. 
Her personal life went through many ups and downs, and Austin wrote on these experiences in several of her works. Her relationships with men, e.g. her father, her brother, and later on her husband, would determine her later criticism of existent gender roles and marriage as a tool of patriarchic exploitation in particular.

While her father had been supportive and loving prior to his death, Austin's older brother was in many ways selfish, although the competition with him urged her to improve and adapt in life. Austin and her brother Jim went to school together, creating even more tension and competition as she was younger but similarly ambitious. After the death of her father, the young girl believed that her brother, the new man of the house, was the favorite of her mother. He got all the attention and accommodations, while Austin was expected to not make a fuss and to know her place as a woman both in the family and in the society of the late 19th century. The present chapter intends to take a closer look at Austin's struggle against existent gender roles and marriage-related norms in the United States in the last decades of the 19th century and the early ones of the 20th century. It will therefore examine Austin's life before her works and respective reflections about the said roles and norms are taken into closer consideration.

\section{Austin's Life and Her Experiences with Patriarchy}

In her autobiography Earth Horizon (1932), Austin recalls her engagement with the women's suffragette movement as a result of the imbalanced relationship between women and men. What fueled her fire to become hard-headed was based on a personal story regarding the unfair demands that were put on her by her mother to submit to whatever her brother had decided upon as a rule for the household, e.g. "a four-minute egg."” The author later recalled the family's reactions to her divergence by not conforming to the idea that she had to eat the same soft-boiled egg as everyone else. The experience of soft-boiled eggs unsettled her in the morning, and upon asking if her egg could be boiled a minute or two longer, the question was not received positively but led to a conflict between her individual wishes and the patriarchic norms of her home. It became a constant annoyance and led to comments from Jim, such as "somehow you never

senkampf: Die "Frauenfrage" aus deutscher und internationaler Perspektive im 19. und 20. Jahrhundert, eds. Vincent Streichhahn and Frank Jacob (Berlin: Metropol, 2020), 222-239.

3 Mary Hunter Austin, Earth Horizon: An Autobiography (Boston/New York: Houghton Mifflin, 1932), 129. 
seem to have any feeling for what a home should be,"4 or her mother, who argued, "Oh, Mary, why do you always have to have something different from the rest of the family." 5 The rest of the family obviously had no problem with following the patriarchic decision of Austin's older brother, but the young girl felt cheated out of a possible choice.

In 1890, after graduating with a teaching degree, it was made clear that she had been excluded from her family's farm ventures and financial interests. The young woman deemed this decision to be absolutely unfair, as she considered it only right that she and her older brother would get an equal amount of help to start their lives. The hurt made the young Austin realize that her "only" option to build a life of her own was to get married-as a husband would provide safety in life that she herself could not provide alone. ${ }^{6}$ These issues had been criticized by other early feminists, e.g. the anarchist Emma Goldman (1869-1940), who argued that marriage would not provide a safe environment for mistreated girls but would establish just another form of patriarchic exploitation. ${ }^{7}$ Marriage was consequently also a destructive change for Austin in many ways because, prior to her decision, it was not an option or important for her, especially not since she had put so much effort into finishing her studies, despite sickness and delays. ${ }^{8}$ Austin would later reflect upon this step as follows:

[I]t wouldn't just naturally present itself to the modern young woman that this meant Mary wasn't to nullify the effort of her schooling by getting married immediately on leaving school. Mary often knew her mother's contemporaries to shake their head over girls whose mothers had been known to train their resources to put them through college. “What a waste,' they said; 'they'll only get married as soon as they're out.' But the implications of emphasis on the word man went deeper and revealed what not one of the women who used it would admit, that the secret concern of women of that time was family limitation. ${ }^{9}$

Austin here describes how she had been wasting her education on a man, promising her mother she would not "throw it all away" if the latter just helped her through it. Her narration of this time is harsh and critical: "as I recall those later nineteenth-century decades, all the disabilities of excessive child-bearing were

4 Ibid.

5 Ibid.

6 Augusta Fink, I-Mary: A Biography of Mary Austin (Tuscon, AZ: University of Arizona Press, 1983), 54.

7 For a detailed discussion of Goldman's view about marriage, see Frank Jacob’s chapter in the present volume.

8 Austin, Earth Horizon, 162.

9 Ibid. 
charged to the horrid appetites of husband."10 Austin's criticism of a lack of intelligence when discussing family limitations was rather ahead of her time. In 1932, she wrote that educated women had not yet "come into use" and that she had "cheerfully" promised her mother not to waste the resources spent on her education on marriage but would rather "make something of her education," while she was secretly also wishing for five children to match the social demands for women at that time. ${ }^{11}$ It becomes clear that there was a shift in ideas about the ideal of family and marriage in Austin's time, i.e. between the late 1880s and 1930s, and the transformation of old toward new types of family dynamics took place during these decades and could be witnessed by Austin. The majority of women did not work besides their husbands until the $1920{ }^{12}$ All family systems had structures and obligations, while political rights and labor division suited the social dominance of men with regard to the existent "structures" of each family. The socio-economic relationship within the family would naturally, for Austin too, represent the first instance to generate the social role of a woman. ${ }^{13}$

Prior to marrying Stafford Wallace (1862-1931), Mary's wish for a family structure of her own was not something she was particularly looking for, and her dating life was not an exciting one, as she later recalls:

Toward the end of sophomore year, one of them [the young men in Austin's neighborhood] had let her know handsomely that she met all the requirements of what a preachers' wife should be, and he thought they might as well be engaged. Confronted with the enormity of telling a serious young man that she'd rather be dead than married to him [.... ${ }^{14}$

This shows that she never married out of desperation or settled just for anybody, but rather came to the decision of marriage at a point where she saw it as the most pragmatic decision, one she would take according to her own terms. In the summer of 1890, she became engaged, which her mother deemed as her daughter "going out of the family." 15 Around this time, perhaps somewhat selfassured, Austin describes herself at 22 years old and recently engaged as "more than ordinarily intelligent about everything but other people."16 When it came to her new courtship, she was excited, but she also went into her mar-

10 Ibid., 163.

11 Ibid.

12 Stephanie Coontz, "Introduction," in American Families: A Multicultural Reader, eds. Stephanie Coontz, Maya Parson and Gabrielle Raley (New York: Routledge, 1999), xii.

13 Ibid., xv.

14 Austin, Earth Horizon, 172-173.

15 Ibid., 218.

16 Ibid., 220. 
riage with the self-awareness of a young educated woman. Her knowledge about the social institution of marriage made her approach toward it rather diplomatic:

She hadn't taken the first man that asked her, nor at the first time of asking. She had engaged herself to a young man of similar social background of her own, and with a university education. She had been entirely frank as to her intention toward a writing career. She had not concealed the fact of her lack of physical robustness, which she hoped to compensate for by teaching, if necessary, until writing began to pay.

In short, Austin expected her husband to understand that he had not married an unequal wife, but a woman who demanded equality and her own professional outlook for the future.

She gained newfound confidence when she met Stafford Wallace Austin. He was seven years older than her, and Austin described him as "very absent minded but [an] extremely intellectual man." 17 This absent-mindedness set the tone for the rest of their relationship; despite some intellectual stimulus and the practical properties to build a life, there was little romance, which we see in later years affecting the author's opinions in media portrayals about mate-love and successful relationships. Her relationship with Wallace was consequently nothing more than a "modest love."18

This "modest love" never went through any proper flourishment and was more than unsatisfactory as time passed, ${ }^{19}$ thus allowing Austin's selfishness of only caring for her own needs, which she had adjusted repeatedly due to boundaries or negotiations during the engagement, preventing the marriage from lasting. After all, marriage seemed not to comfort Austin, who demanded more for her life than being someone's wife. Despite her relatively "free reign," she was not intellectually stimulated by the marriage, but was eventually left rather bored. At the same time, she contributed close to nothing in terms of domestic tasks, leaving her house in a subpar standard. Despite the lack of much joy, success, or structure in their marriage, the couple's first and only child, named Ruth, was born in the spring of $1892 .{ }^{20}$ The ideal marriage with five children and a loving husband, which Austin had secretly hoped for as a girl, was consequently nowhere in sight.

Austin, who perhaps never would have married if not out of necessity, was ultimately thrown into a marriage and her submission to a husband, as it was

17 Ibid., $54-55$.

18 Ibid., 56.

19 Abraham Hoffman, "Mary Austin, Stafford Austin, and the Owens Valley," Journal of the Southwest 53, no. 3/4 (2011): 307.

20 Fink, I-Mary, 59-63. 
dictated by social norms which the female writer would later contest in her works. Evidentially, this marriage was one of the things that made Austin "special" in a way, because it eventually led to a finalized divorce and turned her into an unconventional woman of her time. ${ }^{21}$

The milestones that were the most celebrated, in contrast to those of her domestic life (such as the birth of her child, etc.), were the ones related to her writing career; the accomplishment of selling her first two short stories gave Austin a great sense of triumph and confidence, and she described it (i.e. the quality of her creative effort) as "this opening movement of an activity that was to mean more to me than anything that was ever to happen to me; quietly as I suppose all growing things begin... there was that stream of knowingness which ever since adolescence I had felt going on in me."22 In terms of how this affected her marriage, it was positive to some extent as well as problematic in others. The confidence in her achievements as a writer gave her the comfort to follow her husband anywhere in his venture to secure a living, knowing that she could always write. ${ }^{23}$ In her third year of marriage, it was Austin who secured a good life financially, a possibility "brought up in a university town where people of intelligence and taste contrive, on incomes little better than those of highly skilled labor to achieve for themselves security and certain of appurtenances of good living," ${ }^{24}$ which was something her husband did not possess. The expectations of a man who was educated and "on her level" was rather disappointing when he was not someone who could hold his end of the union, leaving his wife in a stressful situation where she felt she had to step up more than a wife ought to do at those times. This was positive in the sense that Austin broke barriers by working and making a living, however it also drove a wedge between her and her husband as the relationship became dull and disappointing. Her marriage was eventually determined by a lack of balance and distrust because the partners did not work as a team; while they existed within the same space, they were totally distant from each other.

Moreover, the author was also consumed by her writing and spent the subsequent years following the decisions of her husband when he decided to move to wherever he saw fit to work, e.g. to the Owens Valley. ${ }^{25}$ Although the marriage was already dull in numerous ways, Wallace supported Austin's goals of becom-

21 Karen Langlois, "Mary Austin and Andrew Forbes: Poetry, Photography, and the Eastern Sierra," California History 85, no. 1 (2007): 42.

22 Fink, I-Mary, 62.

23 Ibid., 64.

24 Austin, Earth Horizon, 239.

25 Ibid. 
ing a writer, and it was in that regard that she found the most joy, especially since her husband seemed to provide the support she had never gotten from her family. ${ }^{26}$

An important friend she made at this point in her life, during which she was overwhelmed by her need to write, teaching, taking care of her daughter Ruth, and disagreeing with her husband, who did not wish her to take too many teaching commitments so she could be at his disposal at home, was Miss Williams. ${ }^{27}$ Miss Williams taught at an Indian School located in a reservation, and it was through her that Mary got the opportunity to connect with the Native American population close by and got the benefit of visiting them on their land. The friendship gave her both the companionship she was not getting from Wallace and was also fruitful for her thoughts and writings. During this time, Austin was made aware of the abuse and mistreatment the Native Americans in the area (Paiute) were suffering from. ${ }^{28}$ Specifically, the attacks on and sexual abuse of native women in a practice called mahala chasings, ${ }^{29}$ in which Native American girls working in town as housekeepers were attacked and raped on their way home from work, made Austin furious. Often, the young women and girls were not only raped but also harshly beaten. ${ }^{30}$ To observe such injustices matured Austin considerably, in addition to her own divorce at a time in which this was not "normal."

\section{Marriage and Gender Norms in Austin's Works}

The occurrences of a divorce matured something in Austin, and her pen(wo) manship began to move beyond its early focus on Native American tales, mining, and sheepherding traditions in the regions she had lived in. This shift came when her marriage began to break around 1905. Her literary skills ripened into a new stage, focusing more on the hardship of women's lives in the West, a prime example being one of the stories in Lost Borders (1909), “The Bitterness

26 Ibid.

27 Fink, I-Mary, 83.

28 Ibid., 84-87.

29 Janis P. Stout, Picturing a Different West: Vision, Illustration, and the Tradition of Cather and Austin (Lubbock, TX: Texas Tech University Press, 2007), 84. Also see Melody Graulich, ed. Western Trails: A Collection of Short Stories by Mary Austin (Reno, NV: University of Nevada Press, 1987), 9; Glenda Riley, A Place to Grow: Women in the American West (Arlington Heights: Harlan Davidson, 1992), 189.

30 Fink, I-Mary, 84. 
of Women," which explores domestic relations gone wrong. ${ }^{31}$ It paints a picture and explores how in "the treacherous desert country men are lost, children die, [and] women who wish to become wives and mothers live wasted lives." 32 This is the point from which the writer further evolves and deliberates more broadly on the theme of women not making a life for themselves without a man, into which she is not only projecting her own life but also putting other women's experiences into words, among whom are the Native American women she encountered in the desert as well as her mentors such as the novelist Charlotte Perkins Gilman (1860-1935). ${ }^{33}$ Gilman served as a prime example of what Mary wanted to be: someone who had suffered an unhappy marriage, who had been accused of being an unsuitable mother, and who had had to give her children over into someone else's care, yet who was still fighting for the social and economic liberation of women and for a transformation of existent gender roles. ${ }^{34}$

Austin would then also spend almost two years traveling in Europe, especially in Italy, and she also visited London. During her European years she met and became friends with individuals such as George Bernard Shaw (1856-1950), W. B. Yeats (1865-1939), and H. G. Wells (1866-1946), who were people she absorbed strength from. ${ }^{35}$ Her "feminist" intellectuality and properties developed greatly due to her attending a British socialist meeting of the Fabian Society in London. ${ }^{36}$ This society was appealing not only because of the influential literary individuals that were involved but also because of their support for Austin's fundamental aims, i.e. politics for women and their concerns; the Fabian Society was in support of the suffragette movement in Great Britain. ${ }^{37}$

31 Karen S. Langlois, "A Fresh Voice from the West: Mary Austin, California, and American Literary Magazines, 1892-1910,” California History 69, no. 1 (1990): 32-33.

32 Ibid., 33.

33 On Gilman's life and work see, among others, Catherin J. Golden and Joanna Schneider Zangrando, eds., The Mixed Legacy of Charlotte Perkins Gilman (Newark, DE: The University of Delaware Press, 2000).

34 Fink, I-Mary, 84-100.

35 Blanche H. Gelfant, “'Lives' of Women Writers: Cather, Austin, Porter/and Willa, Mary, Katherine Anne," NOVEL: A Forum on Fiction 18, no. 1 (1984): 66.

36 Benay Blend, "Mary Austin and the Western Conservation Movement: 1900 -1927," Journal of the Southwest 30, no. 1 (1988): 13.

37 Derril Keith Curry Lance, "The Suffragette Movement in Great Britain: A Study of the Factors Influencing the Strategy Choices of the Women's Social and Political Union, 1903-1918” (MA Thesis, University of North Texas, 1977), 61. 
In Mary Austin's Regionalism: Reflections on Gender, Genre, and Geography, ${ }^{38}$ German scholar Heike Schaefer sheds light on Austin's take on the dilemma and "bitterness" of women in various stages of life, e. g. marriage and the domesticity of that institution.

Austin often examined different dilemmas women had to face in society, particularly when they (much like herself) were self-determined, professionally ambitious, and family-oriented women, who were, however, limited by the existent gender roles and the social expectations for women. ${ }^{39}$ In her personal life, Austin had to choose between family life and her career, which is exactly the same narrative many of her protagonists have to follow as society does not allow them to "have it all." Independent and norm-defying characters are a staple in Austin's literature and reflect both who she was herself and whom she wished to become.

Mary Hunter Austin's personal story consequently deserves to be studied closely because it is not only the base for her own career as a successful writer but also the base for her stories. The people with whom she interacted influenced her intellectually but also challenged her identity as a woman, both positively and negatively, and it is in these interactions we find many answers to why she fought for gender equality and contributed to changes to gender roles.

Austin's mother would, instead of encouraging her daughter, blame possession for being the reason for the girl's odd behavior, a fact that created even more distance between them. ${ }^{40}$ As a woman with the responsibility for her household, she did not understand or appreciate Mary's vivid imagination and her lack of self-control in speaking whatever was on her mind, dismissing social cues of politeness-much to her mother's frustration and dismay. ${ }^{41}$ The lack of female connection resulted in some level of mental isolation, and from an early age Austin developed an alter-ego, a braver and bolder version of herself referred to as "I-Mary," which to her was more than just Mary-by-herself. She (I-Mary) had no need to be understood and did not mind being different: "To be I-Mary was more solid and satisfying than to be Mary-by-herself." ${ }^{42}$ She protect-

38 Heike Schaefer, Mary Austin's Regionalism: Reflections on Gender, Genre, and Geography (Charlottesville, VA: University of Virginia Press, 2004), 244.

39 Ibid. For a detailed analysis of Mary Hunter Austin's impact on gender roles in the US, see Mohammed, "Mary Hunter Austin."

40 Fink, I-Mary, 9.

41 For further reading on the relationship between Austin and her mother, see Elizabeth Wright, “Mary Hunter Austin (1868-1934)," in American Women Writer 1900-1945: A Bio-Bibliographical Critical Sourcebook, ed. Laurie Champion (Connecticut: Greenwood Publishing Group, 2000): $13-19$.

42 Austin, Earth Horizon, 47. 
ed herself with this kind of armor and felt brave whenever she needed to be stern and confident during the upcoming years of her life into adulthood

The American academic Esther Stineman writes that "Austin had many reasons to write her story, not the least among them was to vindicate herself from the onus of deserting her husband and placing her child in an institution, personal agonies that colored her writing and career." 43 The sorrow of a failed marriage was probably something Austin could recover from, as her years in New York were greatly determined by the contact with like-minded women (i.e. free women), but a child in an institution that she could not give a proper life to by herself was another sorrow only a mother could feel. Perhaps it is not too presumptuous to claim that everything Austin did and wrote, whether it was about love, marriage, war, or a particular landscape, was a way of taking control of her identity as a woman and improving her own self at a crossroads. She claimed that she felt misunderstood and that writing was a way for her to express herself in a wholesome manner and pay her respects to all the things she saw in a way that others did not. ${ }^{44}$

Austin had been peculiar in many ways from an early age, and this statement remains valid when it came to the opposite sex, because despite having an interest in boys, they seemed less keen on her-later this became a proud moment for her, as she used this to focus on her career and intellect. In adulthood, “Austin's views seemed impractical to economists, legislators, and businessmen who focused on the economic possibilities of the Southwest," ${ }^{45}$ but she was still passionate to the point where the impracticality did not matter, and the cause made sense; indeed, it was this drive that she took with her further into her living years. Throughout her life, Austin became tremendously dedicated to finding solutions and putting an end to the conflict between nature and culture; she saw people as a reflection of the land and the wilderness of individuals linked to the wilderness of the flora and fauna. Austin's ideas and the idea of the socially constructed gender as we define it in our time are similar in many regards as they attempt to let go of limitations. Gender (and nature in Austin's case) should not be construed as an unchanging identity but be remotely constituted in time, defined by the space through a performative-vague and wild. ${ }^{46}$ Much like how we as humans exist and insist on our presence, Austin defined nature

43 Esther Lanigan Stineman, "Mary Austin Rediscovered," Journal of the Southwest 30, no. 4 (1988): 550.

44 Austin, Earth Horizon, 47.

45 Blend, "Mary Austin and the Western Conservation Movement," 21.

46 Judith Butler, Gender Trouble: Feminism and the Subversion of Identity (New York/London: Routledge, 2006), 140. 
as something that "insists on itself." ${ }^{47}$ Despite the hardship the Hunters experienced in the land, the young woman was content because the unconventional society felt more suited to her. ${ }^{48}$ The term normal to specify averageness was not something that had yet been categorized, however the idea that there was a human norm, and that this norm was "the average man," was set; thus, a display of difference from women was categorized as a weakness of the female sex and of their intelligence both mentally and physically. ${ }^{49}$ She defined and criticized stereotypes of women at the time by being outspoken on matters where women did not have a big role, such as the environmental issues present in her activism and literature, and is described as creating a "feminist alternative to the masculinist myths of the far West as a place where men achieved heroism either by conquering the wilderness or by communing with it in solitary ecstasy." ${ }^{50}$ Austin desired to find the fundamental value of nature, and thereby herself as a woman, and therefore she wished to overcome hierarchical traditions in Western culture that imply that the desert is a wasteland or that men control nature, and in the process, she became an advocate for Native American rights as well as gender equality. ${ }^{51}$ These values of hers started in the early stages of her youth and were cultivated all through her life as she matured. One can argue that because of the lack of emotional support from her family, and later in life, her husband as well, she looked to the flora and fauna of the desert for clues to survive under difficult conditions. Nature became her safe zone and focus point alike, especially since she must have felt alone quite often. Independent and self-defined, even borderline selfish and self-centered, her attitude often made her an outcast in the various Western towns where she lived during her lifetime. Consequently, Austin shared with other desert appreciators the strong sense of herself as a nonconformist who sought comfort in the spirituality provided by the land. ${ }^{52}$

Despite having a husband/marriage, it was in other women that Austin found companionship for most of her adult life. These women all fought for something, often correlating with the author's own battles and later activism.

47 Blend, "Mary Austin and the Western Conservation Movement," 16-17.

48 Ibid.

49 Melody Graulich, “Mary, Mary, Quite Contrary,” The Women’s Review of Books 1, no. 4 (1984): $16-17$.

50 Lois Rudnick, “Review: Feminist on the Frontier," The Women's Review of Books 7, no. 7 (1990): 22.

51 Vera L. Norwood, "Heroines of Nature: Four Women Respond to the American Landscape," Environmental Review 8, no. 1 (1984): 41.

52 Blend, "Mary Austin and the Western Conservation Movement," 16-17. 
Some of the women the author encountered in her lifetime were inspirations and some were comforts in their similarity to her. Austin also "never attempted to separate her art from her politics," 53 and going against what was considered "normal" determined Austin's life as an activist. This is clearly the case as it influenced the writer in her journey of self-discovery within the areas of politics and her socio-cultural understandings. Her political views on society were impacted by the injustice she saw in the male-dominated (i.e. patriarchic) culture she was surrounded by. "Austin was always a political activist - so much so that her career as a writer may have suffered because of her commitment to a variety of social causes which seem now presciently in advance of her time." ${ }^{24}$ Almost above all else, Austin was a firm believer that men's experience could not speak for women, as she thought that women's vision for "selfhood" was considerably different from men's. ${ }^{55}$ These ideas also inspired her grand, almost scandalous ideas, such as the freedom of choice in mating and the role of marriage bureaus. ${ }^{56}$ Marriage bureaus were organizations that men and women joined in order to find a husband or a wife. Essentially, the idea was to sign up to arrange the meeting of a potential husband or wife who wished for the same thing. Based on Austin's plea to make these state-run (a municipal matter) shows that they were seen as helping to give people more options; it showcases that the bureaus would increase the number of more successful marriages that would not end in divorce. The production of marriage certificates had become an efficient business by the 1900s, and clerics had books containing blank marriage certificates that were ready to go in minutes, making them efficient machineries. ${ }^{57}$ In 1912, The New York Times published the notion to "make marriage a trade" 58 as it was printed that in both "Jersey City and Newark," i.e. City Halls, "marriages had become a traffic. In both of the municipal buildings there are clerks employed in department offices who are also Justices of the Peace. The marrying clerks have had the License Bureau 'shadowed' for the love-lorn..." ${ }^{59}$ Austin was a firm believer that "the real romance is the right marriage," and the idea of "mu-

53 Graulich, "Mary, Mary, Quite Contrary," 16-17.

54 Gelfant, “'Lives' of Women Writers,” 69.

55 Graulich, "Mary, Mary, Quite Contrary,” 17.

56 Doris E. Fleischman, "Mary Austin Thinks Freedom of Choice in Mating Is Merely Nominal Here, Therefore the Novelist Urges Municipal Marriage Bureaus," New York Tribune, December 18, 1914, 7 .

57 “Marriage Bureau Complete," The New York Times, December 5, 1900, 5.

58 "Make Marriage a Trade," The New York Times, January 6, 1912, 10.

59 Ibid. 
nicipal 'soul mating""60 would contribute to solving many socio-economic problems. "To love, to be loved, to marry and to keep on loving - that is the only perfect and possible ideal for men and women." ${ }^{61}$ The author encouraged the idea that town/city halls should not only be for the business of the marrying but also for the meeting: "there is no reason why each town should not have large halls or public meeting rooms where, under municipal chaperonage, the social life of the young may be married on." 62 The idea was that it would help young people "start right" in their pursuit of perfect partnerships which would ensure success in all aspects of life. Marriage, both before, during, and after, should be a matter that society concerned itself with, according to the author, who in 1913 firmly stated that "society should stand by [a] woman raising [a] family." ${ }^{3}$ The bearing and raising of children, which women did, was something she saw as the highest form of service, to which a woman gives 20 years of her life. During that time, "she has a right to expect society to stand by and see that the security of her married life is not a disturbed by any trivial or unworthy occasion." "64 The author's opinions on marriage and motherhood can be divided into two parts. Firstly, a woman's worth is not only that of her belonging to the first man who asks for her hand in marriage and of her ability to reproduce. Secondly, and most importantly, a woman is to marry-but after careful consideration and on the basis of love. Motherhood, although not the only thing to determine the value of a woman, should be regarded as the highest of sacrifices and treated with respect and ensured security.

In her writings, there was always a narrative in which the protagonist had to make the hard choice between love and career, family and the self, and so on, and thus it is not so strange that she would encourage something like "municipal marriage bureaus." Austin argues that there is nothing wrong or disreputable about openly seeking a mate and wishing for such marriage bureaus to arrange relationships legitimized by the state. The author actually believed that the state did not do enough for married people, besides giving its name to sanction marriages, but no one could go to the state for advice or aid in what she labeled "the most important business of this world." 65 Although there were plenty

60 "Municipal 'Soul Mating."” Bryan Daily Eagle, March 4, 1914, 4; the same article was also published on the same day in The Daily Star Mirror.

61 Ibid.

62 Ibid.

63 Mary Austin, "Mary Austin Says White Slave Trials Mark Dawn of New Era for Women," The San Francisco Call, September 5, 1913, 3.

64 Ibid.

65 Fleischman, "Mary Austin Thinks Freedom,” New York Tribune, December 18, 1914, 7. 
of private marriage bureaus, that alone was not good enough for Austin, who considered them to be merely matrimonial agencies, which were all creditable in accomplishment. This demand, however, could obviously lead to misunderstandings: "In the modern era of freedom of choice it seems a step back to continentalism, the idea of having one's mate picked out for him. But it is just that freedom of selection which Mrs. Austin desires to augment in her scheme. The further we get away from barbarism and ignore it the more we realize the necessity of freedom of selection in our marital relation."66

Austin argued on the basis of the "average person having no chance in marriage," having asked "many," who all confirmed that there was not a great selection, while most only had one option or suitable acquaintance: "how can they be expected to make happy marriages if they are forced to marry the one person man or woman they know?"67 It is somewhat difficult to fully understand what Austin truly wished to achieve by such a "sacred business"; the best possible love? Or the best possible business/practical outcome of a union between a man and a woman? "People wouldn't be unhappy if they were sure they loved each other when they married. It is only those who marry for other reasons than love that swell the numbers of the divorce list. And there is a very great number of them." 68

The idea that men and women marry for "a home," or at least their idea of one, should not be the only incentive when choosing a mate. Additionally, she labeled many young men and women as "tragic" because it was a group of hard-working people whom time had passed by and who lacked the option of finding anyone available. Overall, the idea of making marriage the responsibility of the state was a pragmatic idea of Austin, but it also shows clear evidence of perhaps saving others from the fate of her own life. Maybe she had hoped that such bureaus could prevent unhappy and unequal relationships, like the one she had experienced herself. Austin encouraged the investigation of people's characters in these bureaus and not just taking any and everybody at face value. In a way, such arguments emphasize that Austin had a rather scientific approach to marriage, which should be considered a pragmatic choice according to the partner's profile rather than a purely love-related decision. Only such a form of stateorchestrated marriage could have prevented exploitation of any form as well. The idea of municipal meeting halls for young people, "under municipal chaperonage," ${ }^{69}$ was also a rather clever plan toward labor: "a married woman is out of

66 Ibid.

67 Ibid.

68 Ibid.

69 “Municipal ‘Soul Mating,” Bryan Daily Eagle, March 4, 1914, 4. 
her job when her children are sixteen or eighteen years old, or surely when they become married. State chaperon would be a most delightful occupation. She had experienced in being a personal mother, and she will enjoy being kind of a public mother." This was a rather clever ploy toward both helping people find "practical and suitable" partners as they become presented with more options and securing women an occupation upon their expiration as mothers-since that was a woman's shelf-life; girl, wife, mother, and then out of purpose. The state as the overseeing institution would consequently guarantee that women would be granted a safe and secure marriage with a suitable partner. Maybe Austin had hoped that equality could be secured that way, as the traditional and exploitational patriarchic marriage would eventually end through this practice.

\section{The Modern Woman and (Demolishing) the Institution of Marriage}

In 1895, American journalist and author Elizabeth Bisland (1861-1929) wrote that "criticism of the marriage relation is in the air"70 and how fiction was the arena in which these discussions were being held. Many women like Austin would begin to discuss these matters in the upcoming years, as well as the traditional roots and gender roles that had determined family matters for so long. ${ }^{71}$ Bisland makes the argument that mutual affection for a child is what essentially held a family together. The argument is that a father's love was cultivated, while the love of a mother was instinctive. ${ }^{72}$ In Austin's own childhood, however, her mother was emotionally distanced, although this is a rather subjective narrative bestowed upon us in the author's autobiography and can probably be argued in many cases as dramatic/exaggerated. Overall, her father was her emotional support, and her loss after his early death was a loss no one else could fill.

With Bisland's argument of cultivation and instinctive love and Austin's own experience with missing a parent (i.e. a key role), one would assume that she fell into the norm after the birth of her own child. However, her daughter was born (in 1892) with a mental disability, which created distance, stress, and what was perceived as a personal maternal and marital failure-she was shamed by her own mother, who believed this was some sort of punishment/judgment upon

70 Elizabeth Bisland, “The Modern Woman and Marriage," The North American Review 160, no. 463 (1895): 753.

71 Ibid.

72 Ibid. 
the author. ${ }^{73}$ Her own life and marriage not working out exceptionally well in its earlier years, Austin went on to advocate for successful love and marriage, and, as someone who had experienced it "all," 74 built the basis of her ideal partnership on more practical things, such as work and income. Her circle in New York and the people she corresponded with encouraged these ideas and a change of gender norms.

While living in New York, Austin befriended the rich supporter of the arts, Mabel Dodge Luhan (1879-1962), who arranged "evenings," as she called them. ${ }^{75}$ A remarkable group of people attended these events, such as suffragist, actress, and poet Ida Rauh (1877-1970), labor leader and feminist Elisabeth Gurley Flynn (1890 -1964), writer and activist Max Eastman (1883-1969), writer and social reformer John Collier (1884-1968), and political commentator and reporter Walter Lipmann (1889-1974), just to mention a few among the socialists, journalists of all kinds, trade unionists, anarchists, artists, clubwomen, suffragists, poets, psychoanalysts, "and even an occasional murderer."76 It was here that Austin met people who made her feel "normal," because she was surrounded by other outsiders, which surely encouraged her deeds toward modernity.

One of the events was particularly arranged for "dangerous characters," which included the Russian-Jewish anarchists Emma Goldman and Alexander Berkman (1870 - 1936). ${ }^{77}$ Also present was Elizabeth Gurley Flynn, who was the person responsible for introducing Austin to Goldman. ${ }^{78}$ Evenings such as this, in the company of most radical individuals, created bonds across class and ideologies ${ }^{79}$ and were without any doubt fruitful for Austin's growing determination and acted as inspirations.

Goldman was one of the most recognizable radical faces of the anarchist movement prior to the First World War, having been arrested multiple times and known as "the high priestess of anarchy," 80 becoming the ultimate symbol of anarchist protest in the early 20th century in addition to her writing/editing

73 Fink, I-Mary, $70-78$.

74 Mary Hunter Austin, Love and The Soul Maker (New York: D. Appleton and Company, 1914).

75 Fink, I-Mary, 167-168.

76 Ibid., 168.

77 Emily Hahn, Mable (New York: Houghton Mifflin Company, 1977), 67-71. For further reading on notable individuals in New York at that time, see Emily Hahn, Romanic Rebels: An Informal History of Bohemianism in America (New York: Houghton Mifflin Company, 1967).

78 Austin, Earth Horizon, 326.

79 Allen Churchill, The Improper Bohemians (New York: E.P Dutton and Company 1959), 56-58.

80 Jeffrey A. Johnson, "Aliens, Enemy Aliens, and Minors: Anti-Radicalism and the Jewish Left," in Historicizing Fear: Ignorance, Vilification, and Othering, eds. Travis D. Boyce and Winsome M. Chunnu (Boulder, CO: University Press of Colorado, 2020), 200. 
in the anarchist journal Mother Earth (established in 1906) ${ }^{81}$ It is therefore interesting in many ways how Goldman and Austin came to cultivate a friendship in which being an outspoken and profound individual was respected and celebrated.

Although both women were politically left, the mainstream media treated them differently in relation to the US entry into the First World War. Goldman was stereotypically depicted as "a money-hungry Jew" wishing to profit off her publication (i.e. Mother Earth), described as a money-grabbing opportunist and "shrewd [individual] ... who for many years has made anarchy a well paying [sic] profession." ${ }^{2}$ Although Austin wrote for a living as well, she was not accused of the same.

Around the same time as Goldman was being ostracized and villainized due to the nationalist tensions that had been created due to the war, ${ }^{83}$ Austin was celebrated for her works, e.g. "Sex Emancipation Through War," ${ }^{4}$ a political essay published in 1918 which can best be described as a feminist work. In it, the author reflects on how women are in need of emancipation through work, which would secure safety for them because the social structures were all far too accommodating for the man. Austin especially thought of economic exploitation in relation to female gender identity and conveyed the idea of how it is but a superstition that the work a human being does or may do is determined by sex. She argues against the social value of a woman being established by what some man thinks of her and how it is utterly ridiculous that the man must be the sole provider for the family. This is a clear criticism against existent family structures, i.e. marriage, in which there is a homemaker (woman) and a bread-winner (man); women's emancipation would solve it "all."85

Mobilization for war as a form of independence for women was among the things that female crusaders had in common; the notion that every American woman, rich or poor, married or single should be able to earn her own living was a collective thought among the likes of Austin. ${ }^{86}$ The idea was that labor would ensure a freedom that would protect against "old maid's fate," which

81 Ibid.

82 Ibid.

83 For further reading on Goldman's alienation in America, see Frank Jacob, Emma Goldman and The Russian Revolution: From Admiration to Frustration (Berlin: De Gruyter, 2020), 85-118. 84 Mary Austin, "Sex Emancipation Through War" in Beyond Borders: The Selected Essays of Mary Austin, ed. Reuben J. Ellis (Carbondale, IL: Southern Illinois University Press, 1997), 44-55. 85 "The May Forum," Chicago Eagle, May 11, 1918, 5.

86 Marguerite Moors Marshall, "Mobilizing the American Girl into an Industrial Reserve Force is Insurance Against Old Maid's Fate,” The Evening World, March 6, 1917, 3. 
was to be avoided, as marriage was inevitable for survival but also something that was going through social change, as social reforms were shaping society and women's roles in new ways.

Well-educated, middle-class women such as Austin played a key role in pushing progressive reforms and fighting this idea of "old maid's fate." The club movements helped women develop public opinion and carve out a space for themselves, and increasingly gained a political voice even without the right to vote (yet). ${ }^{87}$ Among the places in which activism played out and sustained itself was in networks of female friends who wished to make social reform, not marriage, the focus of their lives (e.g. wealthy women joining immigrant women workers in an effort for the right to vote, unionization, and the improvement of factory conditions). ${ }^{88}$ Women's social reform solidarity maintained a great level of purposefulness because the interests of women and children became a federal matter through these social welfare networks, ${ }^{89}$ e.g. the idea that arranging good marriages through bureaus on a municipal level such as those Austin advocated to benefit women in getting a balanced and equal marriage was part of the collective effort toward all aspects of social change for the objective prosperity of all partners equally.

Austin did not dismiss the need for sexes (i.e. man being man and woman being woman), as she contends that there are undoubtedly important and unchangeable differences between the abilities of the two, but argued that the war had been a good thing because it had demonstrated that the differences are not that fundamental in the grand scheme of things ${ }^{90}$ (e.g. working as a woman and earning wages): "in other words, it is not so much brains as nervous stability that is required." 91

Despite Austin being a leftist who should have been more critical of war, she considered it to be a good opportunity for change. Maybe this made her chaotic and someone who played on all fields, or maybe she was just eclectic and pas-

87 Ellen Skinner, Women and the National Experience: Primary Sources in American History (Boston/New York: Addison-Wesley Educational Publishers Inc., 1996), 115.

88 Ibid., 149.

89 Ibid., 172.

90 Birgitta Bader-Zaar, "Controversy: War-related Changes in Gender Relations: The Issue of Women's Citizenship,” in 1914-1918-online: International Encyclopedia of the First World War, eds. Ute Daniel, Peter Gatrell, Oliver Janz, Heather Jones, Jennifer Keene, Alan Kramer, and Bill Nasson, issued by Freie Universität Berlin, October 8, 2014, accessed March 3, 2021, https://encyclopedia.1914-1918-online.net/article/controversy_war-related_changes_in_gen der_relations_the_issue_of_womens_citizenship.

91 Austin, "Sex Emancipation," 49. For further reading on women and their employment conditions, see Skinner, Women and the National Experience, 172-176. 
sionate, but overall, she demanded change with regard to the social core structures. The narrative of "Sex Emancipation" is not critical of the war, nor does it have a negative narration toward men (and a positive one toward women); however, it determines the idea that women (married or not) are more than capable of doing jobs that have traditionally been non-female friendly-this also applies to the female role in existent family structures, determined by pre-set roles for husbands and wives.

The criticism she presents is related to the assumption that a woman has no value to society except the one a man assigns her-making her the object of his desire and the mother of his household:

There is no history of the development of the idea that a woman has no value to society except that which man gives her, as the object of his desire and the mother of his children.... Men sacrifice themselves to womanhood, its racial function; they sacrifice themselves and the world to their love for a particular woman. But whoever heard of a man putting himself aside because the world needed some woman's gift for architecture, or biology, or sociology, more than it needed his contribution..$^{92}$

Much like her criticism from girlhood about women throwing away their education to marry, wasting the resources spent on their education, she also blames men for this: "men have never hesitated to take a woman out of society and insist that every gift, every possible contribution of hers to general human welfare shall be excised, aborted, done with." ${ }^{\text {93 }}$ This is a clear disapproval of the social structures that rule that a woman belongs to a man-whether it be a husband, father, or brother to decide as he pleases. Austin stood for the idea that the world was a very feminine place, meaning a mother's place, making it conceptive, brooding, nourishing, and a place of infinite patience and elusiveness. ${ }^{94}$ However, although it might come across as her dismissing marriage, she was critical of its norms rather than its existence as such. She fought so that the social structure of marriage did not define the entirety of women's value or discredit their positions as equal citizens.

In her fiction, she spoke freely, although she was somewhat afraid people assumed her social criticism came from a person who did not know love or the hunger to speak about it (for change): "few men understand what that hun-

92 Ibid., 50.

93 Ibid.

94 Teena Gabrielson, "Woman-Thought, Social Capital, and the Generative State: Mary Austin and the Integrative Civic Ideal in Progressive Thought," American Journal of Political Science 50, no. 3 (2006): 656. 
ger is in women ... like the opium-eater's for his drug." 95 In her youth she did not just settle for any man, and she was greatly impacted by her mother. In later years, this particular issue comes up in Earth Horizon when Austin reflects upon meeting Henrietta Rodman (1877-1923), a feminist school teacher who drew the author to the struggle of making a place for married school teachers. ${ }^{96}$

Her personal life and fiction greatly affected each other, and in a newspaper interview, Austin states that the motivation behind her books about the topic of love (e.g. Love and The Soul-Maker) was the need for books that would help people avoid "such a muddle of our loving. Women want such a book, and men need it." ${ }^{97}$ In an interview about Love and The Soul-Maker, the author addresses the notion that parental love is not something that just comes for free with romantic love:

All the things that marriage ought not to do for us may be gathered under the one head of not discrediting our social values. This is the sole criterion of particular marriages with which society had any concern - are parties to it worth more or less to us? ... Nature has experimented with matings a thousand way across the field of life; welded the essential elements in one, divided them, united them in ephemeral tragedy, swept the respective instruments apart though wider and wider ranges of unmatched experience, brought them together for longer and more complicated contacts. ${ }^{98}$

Passion between men and women, Austin claimed, was not just nature's preface to mother- and fatherhood. Romantic love in itself is "the oldest need and strongest instinct of the human race." ${ }^{99}$ Austin presents the prerogative that mate-love (i.e. romantic love between the two sexes) had been so dim in the past that parenthood was looked at as a miracle and the driving force, which in turn made it utterly detached from the romantic love of the husband and wife. The author's wish to shed light on the importance of romantic love is perhaps strongly driven by her own misfortunate marriage; "marriage is an agreement between any pair to practice mate love towards one another with intention." ${ }^{100}$ In many ways, the author is chaotic in what her point is; is love and romance the intention? Or is she pressing the importance of going into a romance with clear intentions?

95 Austin, Love and The Soul Maker, 2.

96 Ibid.

97 Ibid., 8.

98 Ibid., $174-175$

99 Nixola Greeley-Smith, "Mary Austin Discovers Love-Grafters 'Birds of Speckled Feathers'," The Day Book, June 10, 1914, 10.

100 Ibid. 
In her literature, whether political or autobiographical, Austin fought tooth and nail for a bigger change. Perhaps it was to achieve redemption for her own failed marriage, or perhaps it was to save others from the same fate she had gone through. Another notable work that takes a similar critical approach to the institution of marriage is A Woman Of Genius (1912). ${ }^{101}$ The narrative of the work reveals her sense about large female talents and ambitions on the one hand and the demands of love and domesticity on the other; in many ways, it is a tug of war between the self and the demands of the patriarchal society. Ultimately, the idea is that the price of conventional marriage is the destruction of one of the partners. ${ }^{102}$

In The Ford (1917), one can read passages such as "women have a much keener sense of real values,"103 which is something Austin always emphasized: "take marriage, for instance; - a woman will marry a man because he is clean and honest and will make a good father for her children, but a man won't marry a woman unless she makes him feel a certain way."104 This dates back to her 1914 interviews about marriage bureaus and "girls marrying for a home." 105 What the author is presenting are the different intentions based on gender; women think practically about their future, planning for the long-run of family and safety, while men could be self-serving when choosing a mate as they were the providers based on the social constructions of gender and marital structures: "Love in man may change his relation to society, but in woman it changes the woman."106

The ideas in her fiction, in addition to being inspired by her own life prior to 1914, became influenced by the outbreak of the First World War. In addition to her advocacy on marriage for the benefit (social value) of both genders equally, she also implemented this into ideas of how to improve democracy. The war, for example, excluded women, which she strongly advised against, because the idea that democracy could only thrive on the basis of husbands who went to war was not something that society could truly benefit from, according to Austin. She argued that

101 Mary Austin, A Woman of Genius (New York: Doubleday, Page \& Company, 1912).

102 Lee R. Edwards and Arlyn Diamond, American Voices: American Women (New York: Bard Books, 1973), 15-16.

103 Mary Austin, The Ford (Boston/New York: Houghton Mifflin, 1917), 233.

104 Ibid.

105 Fleischman, "Mary Austin Thinks Freedom of Choice," 7.

106 "By and About Women," The Day Book (Chicago, IL), June 5, 1914. 
[c]ivilization as we have it now is one-eyed and one-handed. It is kept going by man's way of seeing things, and man's way of dealing with the things that he sees ... man's method in approaching a new issue is to throw out a hypothesis, a general supposition of what seems likely or desirable to prove true.... This is what women have to stand squarely; not their ability to see the world in the same way men see it, but the importance and validity of their seeing it some other way. ${ }^{107}$

Despite the loudest messages presented by Austin in different instances of her works, it all boiled down to the idea that women should march to the beat of their own drum. This idea challenged the conformity of the time that marriage was a necessity, and Austin rather demanded it be re-defined and restructured to fit the modern woman. A woman should not have to choose between a career and a family, a home or a dull love life, and in later years the author wished for a change to be applied not only to women in marriage and love relationships but also to women's place in society as a whole: "What we women must also hold is the place America has set in the first line of democratic thinking," 108 because man's intelligence and dominance ought not to be the only valid one in the family, in society, and in labor relations. ${ }^{109}$

\section{Conclusion}

Mary Hunter Austin was a strong independent woman at a time when spousal approval was important to be "whole." At times, she needed validation, which she was able to seek and find in her writing more than in a man after her marriage ended. She wanted a society that valued women inside and outside of marriage just as much, as a man was not the only fulfillment a woman ought to achieve in her lifetime. Austin, at the age of 22, "knew more about the marriage as a social institution than most young women of her years" and did not "take the first man that asked her, nor at the first time of asking."

Perhaps her ideas were too advanced for her time, although she expressed them exactly at a crossroads in social history where society needed women like Austin to criticize social institutions, e. g. that of marriage, which were demanded to be transformed for the benefit of women and society's better future. The female writer fought for social change in all aspects of her life; citizenship, gender roles, and all other institutions that ought to limit women or tell them

107 Mary Austin, The Young Woman Citizen (New York: The Woman's Press, 1918), 17-19.

108 Ibid., 9.

109 Ibid., 16.

110 Austin, Earth Horizon, 220. 
they were "less valuable." Marriage was not something she believed should limit women or something that they should just settle for out of necessity, and she encouraged ideals of independent paid work for women that was supposed to lead toward emancipation. This would benefit the modern woman in her independence, as well choosing a mate with caution, rather than taking "the first man that asked" or at "the first time of asking." economically independent enough to make a wise decision that matched their own demands, not the necessities dictated by an exploitative society, whose patriarchic character dictated the roles women were supposed and allowed to play by. Due to her demands, it is relatively unsurprising that Austin was rediscovered as an important voice by Second Wave feminists in later years, who expressed similar demands with regard to equality and the end of patriarchically determined marriages.

\title{
Works Cited
}

\section{Newspapers and Periodicals}

\author{
Bryan Daily Eagle \\ Chicago Eagle \\ New York Tribune \\ The Daily Star Mirror \\ The Day Book \\ The Evening World \\ The Hattiesburg News \\ The New York Times \\ The San Francisco Call
}

\section{Published Sources and Secondary Works}

Austin, Mary Hunter. A Woman of Genius. New York: Doubleday, Page \& Company, 1912. Austin, Mary Hunter. Love and The Soul Maker. New York: D. Appleton and Company, 1914. Austin, Mary Hunter. The Ford. Boston/New York: Houghton Mifflin, 1917.

Austin, Mary Hunter. The Young Woman Citizen. New York: The Woman's Press, 1918.

Austin, Mary Hunter. Earth Horizon: An Autobiography. Boston/New York: Houghton Mifflin, 1932.

111 Ibid. 
Austin, Mary. "Sex Emancipation Through War." In Beyond Borders: The Selected Essays of Mary Austin, edited by Reuben J. Ellis, 44-55. Carbondale, IL: Southern Illinois University Press, 1997.

Bader-Zaar, Birgitta. "Controversy: War-related Changes in Gender Relations: The Issue of Women's Citizenship." In 1914-1918-online: International Encyclopedia of the First World War, edited by Ute Daniel, Peter Gatrell, Oliver Janz, Heather Jones, Jennifer Keene, Alan Kramer, and Bill Nasson. Accessed March 3, 2021. https://encyclopedia. 1914-1918-online.net/article/controversy_war-related_changes_in_gender_relations_the_ issue_of_womens_citizenship.

Blend, Benay. "Mary Austin and the Western Conservation Movement: 1900-1927." Journal of the Southwest 30, no. 1 (1988): 12-34.

Bisland, Elizabeth. "The Modern Woman and Marriage." The North American Review 160, no. 463 (1895): 753-755.

Butler, Judith. Gender Trouble: Feminism and the Subversion of Identity. New York/London: Routledge, 2006.

Churchill, Allen. The Improper Bohemians. New York: E.P Dutton and Company, 1959.

Coontz, Stephanie, Maya Parson and Gabrielle Raley, eds. American Families: A Multicultural Reader. New York: Routledge, 1999.

Edwards, Lee R. and Arlyn Diamond, American Voices: American Women. New York: Bard Books, 1973.

Fink, Augusta. I-Mary: A Biography of Mary Austin. Tuscon, AZ: University of Arizona Press, 1983.

Gabrielson, Teena. "Woman-Thought, Social Capital, and the Generative State: Mary Austin and the Integrative Civic Ideal in Progressive Thought." American Journal of Political Science 50, no. 3 (2006): 650-663.

Gelfant, Blanche H. “'Lives' of Women Writers: Cather, Austin, Porter / and Willa, Mary, Katherine Anne." NOVEL: A Forum on Fiction 18, no. 1 (1984): 64-80.

Golde, Catherin J. and Joanna Schneider Zangrando, eds. The Mixed Legacy of Charlotte Perkins Gilman. Newark, DE: University of Delaware Press, 2000.

Graulich, Melody, ed. Western Trails: A Collection of Short Stories by Mary Austin. Reno, NV: University of Nevada Press, 1987.

Graulich, Melody. “Mary, Mary, Quite Contrary.” The Women's Review of Books 1, no. 4 (1984): 16-17.

Hahn, Emily. Mabel. New York: Houghton Mifflin Company, 1977.

Hahn, Emily. Romanic Rebels: An Informal History of Bohemianism in America. New York: Houghton Mifflin Company, 1967.

Hoffman, Abraham. "Mary Austin, Stafford Austin, and the Owens Valley." Journal of the Southwest 53, no. 2/3 (2011): 305-322.

Jacob, Frank. Emma Goldman and The Russian Revolution: From Admiration to Frustration. Berlin: De Gruyter, 2020.

Jacob, Frank. "Klassendiskurs und Geschlechterrollen im Japan der Taishō-Zeit (1912 1926)." In Geschlecht und Klassenkampf: Die "Frauenfrage" aus deutscher und internationaler Perspektive im 19. und 20. Jahrhundert, edited by Vincent Streichhahn and Frank Jacob, 305-335. Berlin: Metropol, 2020. 
Johnson, Jeffrey A. “Aliens, Enemy Aliens, and Minors: Anti-Radicalism and the Jewish Left.” In Historicizing Fear: Ignorance, Vilification, and Othering, edited by Travis D. Boyce and Winsome M. Chunnu, 193-206. Boulder, CO: University Press of Colorado, 2020.

Lance, Derril Keith Curry. "The Suffragette Movement in Great Britain: A Study of the Factors Influencing the Strategy Choices of the Women's Social and Political Union, 1913-1918." MA thesis, University of North Texas, 1977.

Langlois, Karen S. "A Fresh Voice from the West: Mary Austin, California, and American Literary Magazines, 1892 -1910." California History 69, no. 1 (1990): 22-35.

Langlois, Karen S. "Mary Austin and Andrew Forbes: Poetry, Photography, and the Eastern Sierra." California History 85, no. 1 (2007): 24-43.

Mohammed, Jowan A. "Mary Hunter Austin und die Forderungen nach einer Veränderung der Geschlechterrollen in den USA, 1914-1918." In Geschlecht und Klassenkampf: Die "Frauenfrage" aus deutscher und internationaler Perspektive im 19. und 20. Jahrhundert, edited by Vincent Streichhahn and Frank Jacob, 222-239. Berlin: Metropol, 2020.

Norwood, Vera L. "Heroines of Nature: Four Women Respond to the American Landscape." Environmental Review 8, no. 1 (1984): 34-56.

Riley, Glenda. A Place to Grow: Women in the American West. Arlington Heights: Harlan Davidson, 1992.

Rudnick, Lois. "Feminist on the Frontier." Review of Mary Austin: Songs of a Maverick, by Esther Lanigan Stineman. The Women's Review of Books 7, no. 7 (1990): 22.

Schaefer, Heike. Mary Austin's Regionalism: Reflections on Gender, Genre, and Geography. Charlottesville, VA: University of Virginia Press, 2004.

Skinner, Ellen. Women and the National Experience: Primary Sources in American History. Boston/New York: Addison-Wesley Educational Publishers Inc., 1996.

Stineman, Esther Lanigan. "Mary Austin Rediscovered." Journal of the Southwest 30, no. 4 (1988): 545-551.

Stout, Janis P. Picturing a Different West: Vision, Illustration, and the Tradition of Cather and Austin. Lubbock, TX: Texas Tech University Press, 2007.

Wright, Elizabeth. "Mary Hunter Austin (1868-1934)." In American Women Writers 1900-1945: A Bio-Bibliographical Critical Sourcebook, edited by Laurie Champion, 13-19. Westport, CT: Greenwood Publishing Group, 2000. 
